\title{
Distribution of Grasshoppers (Insecta: Orthoptera) among different host plants and habitats in two districts of Tamil Nadu, India
}

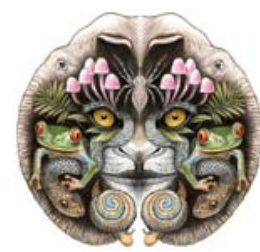

\author{
M. Gabriel Paulraj ${ }^{1}$, V. Anbalagan ${ }^{2} \&$ S. Ignacimuthu ${ }^{3}$ \\ 1,2,3 Entomology Research Institute, Loyola College, Chennai, Tamil Nadu 600034, India \\ Email: ${ }^{1}$ gabriel_paulraj@yahoo.com; ${ }^{3}$ entolc@ hotmail.com
}

Date of publication 26 April 2009

ISSN $0974-7907$ (online) | 0974-7893 (print)

Editor: M.C. Muralirangan

\section{Manuscript details:}

Ms \# 01878

Received 05 November 2007

Final revised received 11 October 2008

Finally accepted 11 January 2009

Citation: Paulraj, M.G., V. Anbalagan \& S. Ignacimuthu (2009). Distribution of Grasshoppers (Insecta: Orthoptera) among different host plants and habitats in two districts of Tamil Nadu, India. Journal of Threatened Taxa 1(4): 230-233.

Copyright: () M. Gabriel Paulraj, V. Anbalagan \& S. Ignacimuthu 2009. Creative Commons Attribution 3.0 Unported License. JoTT allows unrestricted use of this article in any medium for non-profit purposes, reproduction and distribution by providing adequate credit to the authors and the source of publication.

Author Details: M. Gabriel Paulras is currently studying the diversity of insect fauna, mass rearing of biological control agents and screening botanical pesticides against field pests.

V. AnBalagan Research Scholar, is working on pest and natural enemy diversity in agroecosystem for a $\mathrm{PhD}$ degree.

S. Ignacimuthu is the Director of Entomology Research Institute; and formerly was the Vice Chancellor of Bharathiar University and University of Madras. He currently guides Ph.D. students and is involved in research in botanical pesticides, insect diversity, vector control, ethanopharmacology, biotechnology and microbiology.

Author contribution: The study was conducted by M. Gabriel Paulraj and V. Anbalagan under the supervision of Dr. Fr. S Ignacimuthu; Paper was written by M. Gabriel Paulraj and S. Ignacimuthu.

Acknowledgement: We acknowledge Dr. Sanjayan, G.S. Gill Research Institute, Gurunanak College, Chennai, for his help in the identification of grasshoppers.
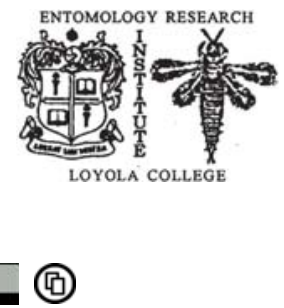

OPEN ACCESS | FREE DOWNLOAD
Abstract: In a survey of grasshoppers in nine localities of northeastern Tamil Nadu, carried out from August 2004 to December 2006, 33 grasshopper species grouped under four families were recorded. Family Acrididae was found to be the predominant group of grasshoppers represented by 21 species, which was $63.6 \%$ of the total species collected. The acridids collected can be classified under seven subfamilies and 15 genera. Family Tettigoniidae was the second largest group represented by six species falling under five genera and three subfamilies, and this family contributed $18.2 \%$ to the total grasshopper species recorded in this study. Among the different habitats, grasses supported the highest number of 18 species $(54.6 \%)$ while 11 species were surface grasshoppers. The painted grasshopper Poekilocerus pictus (Fab.) was collected from many plants viz., Calotropis, curry leaf, grass, groundnut, okra, and on ground. The maximum number of species was recorded from Manimangalam in Kancheepuram District during the entire study period.

Keywords: Acrididae, grasshoppers, host plants,

\section{Tamil Abstract}

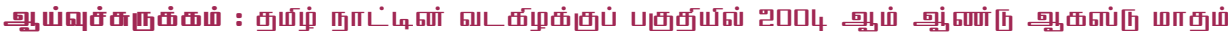

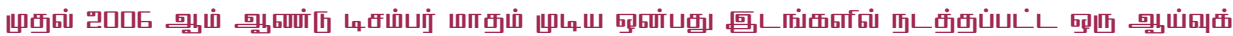

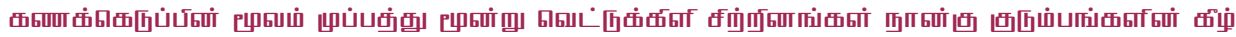

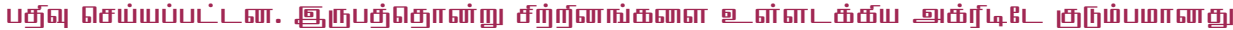

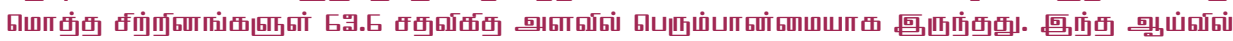

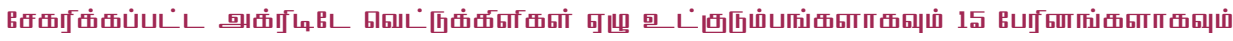

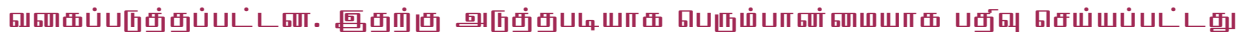

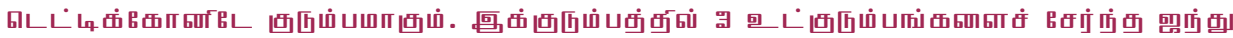

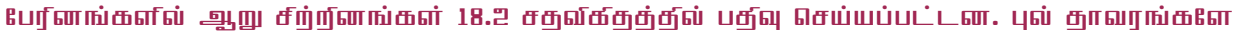

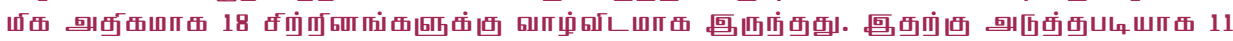

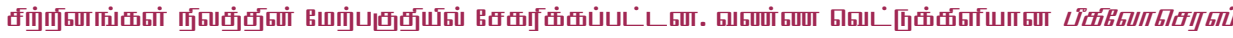

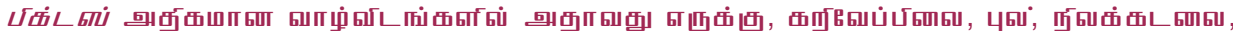

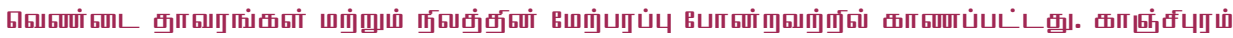

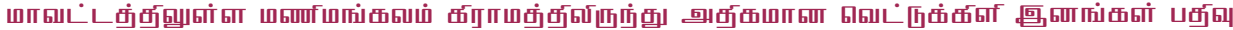
கெய்யப்பட்டแII.

\section{INTRODUCTION}

Grasshoppers are one of the largest and most diverse groups of insects. They are functionally important, being the dominant aboveground invertebrates in pastures and natural grasslands when judged by biomass (Scott et al. 1979; Risser et al. 1981). Some grasshoppers cause significant damage to tree seedlings (Joshi et al. 1999) and agricultural crops. They are also important components of the food chain for many birds and mammals (Capinera et al. 1997; Mayya et al. 2005), and hence resource management practices that alter grasshopper population dynamics will affect several trophic levels in the food chain (Capinera et al. 1997). Most grasshoppers are oligophagous and exhibit definite host preferences (Mulkern 1967), according to which grasshoppers are classified as grassfeeders (graminivorous), forb-feeders (forbivorous) or a mix of the two (ambivorous or mixed feeders) (Isely 1944). Host plant shifting may occur in grasshoppers when their main host is absent, and may indicate the removal of a particular plant species due to environmental degradation or urbanization. In recent years farmers have altered cropping patterns and agronomical practices due to urbanization, labour problems and a desire for greater profits. The changing scenario in agriculture is affecting primary consumers like grasshoppers and thereby creating impacts for entire food webs, thus it is necessary to study the distribution of grasshoppers in relation to their habitats and host plants. Previous studies conducted by Shrinivasan \& Muralirangan (1992), Muralirangan et al. (1992), Sanjayan et al. (1995), Joshi et al. (1999), Kandibane et al. (2004) and Mayya et al. (2005) have added information on grasshopper fauna of different regions of India. The present study was undertaken to record grasshopper fauna from different host plants 
and habitats in chosen localities in Kancheepuram and Thiruvallur districts of Tamil Nadu.

\section{Methods}

Study Area: The survey of grasshopper fauna among different habitat types was conducted at nine different localities: Dhandarai, Kakillapettai, Manimangalam, Nungambakkam, Padappai, Parivakkam, Poonamallee, Thiruvallur and Vayalanallur in Chennai, Kanchepuram $\left(11^{\circ} \mathrm{OO}-12^{\circ} 00^{\prime} \mathrm{N} \&\right.$ $\left.77^{\circ} 28^{\prime}-78^{\circ} 50^{\prime} \mathrm{E}\right)$ and Thiruvallur $\left(12^{\circ} 15^{\prime}-13^{\circ} 15^{\prime} \mathrm{N} \& 79^{\circ} 15^{\prime}-\right.$ $80^{\circ} 20^{\prime} \mathrm{E}$ ) districts of Tamil Nadu. Except Nungambakkam, other localities are rural areas surrounded by agroecosystems. Nungambakkam $\left(13^{\circ} 3^{\prime} 38^{\prime \prime} \mathrm{N} \& 80^{\circ} 14^{\prime} 4^{\prime \prime} \mathrm{E}\right)$ is in the heart of Chennai city.

Host plants and habitats: Grasshoppers that were found feeding on host plants were collected from grasses, Calotropis, cotton, tapioca, brinjal, curry leaf, maize, rice, radish, castor and okra. In the Nungambakkam site grasshoppers were collected from cotton, tapioca, brinjal, curry leaf and okra that were cultivated in a one acre garden at the Entomology Research Institute, and from a one acre ground which contains grasses and Calotropis inside Loyola College Campus. Specimens were also collected from the ground surface inside the sampling sites. The area under cultivation in Dhandarai, Kakillapettai, Manimangalam, Padappai, Parivakkam Poonamallee, Thiruvallur and Vayalanallur ranges from 15 to 3oha with different crops.

Sampling: In each habitat within a location, random sites were sampled monthly with a help of a sweeping net $(25 \mathrm{~cm}$ diameter). Grasshoppers were also collected by hand in the same sites.

Identification: Adult grasshopper samples were sorted to morphospecies and identified up to species level with the help of experts.

\section{Results and Discussion}

A total of 33 species of grasshoppers were collected from different host plants and habitats, and 32 species were identified (Table 1). All the grasshoppers collected are classified under four families viz., Acrididae, Pyrgomorphidae, Tetrigidae and Tettigoniidae. Family Acrididae was the most dominant with 21 species of Acridids grouped under 15 genera of seven subfamilies, amounting to $63.6 \%$ of total collected species. This observation is in accordance with Capinera et al. (1997), Kandibane et al. (2004), Thakur et al. (2004) and Chandra et al. (2007). The second largest family was Tettigonidae with five genera and three subfamilies, which contributed $18.2 \%$ (6 species) of the total collected species, while the Pyrgomorphidae ranked third with $15.2 \%$ of total species collected (5 species) with four genera but with only one subfamily. Tetrigidae was represented only by one species. The trend of numerical distribution of different grasshopper families recorded in the present study is similar to the observations of Andersen et al. (2000), who also reported that Acridid grasshoppers were the largest group followed by Tettigoniidae and Pyrgomorphidae in the Kakadu National Park, Australia.

In a study Muralirangan et al. (1992) have recorded 20 species of acridids under eight subfamilies in different parts of Tamil Nadu. Shrinivasan and Muralirangan (1992) have reorded 18 acridids under four sub families in Tamil Nadu. They have recorded monocot and dicot plants as hosts for acridids. In the present study, seven subfamilies of acrididae have been recorded and they colonized in more diverse habitats such as grasses, groundnut, rice, tapioca, cotton, maize and brinjal fields and ground surface, suggesting that the Acridids are well adapted for colonizing different habitats and are capable of feeding and utilizing a wide range of host plants. Pyrgomorphids and tettigonids were collected from seven and five habitats respectively. Among the different habitats, grasses were found to be the most common habitat for grasshoppers (54.5\%) (Table 2). Capinera et al. (1997) found that the gramnivorous grasshoppers were the most abundant probably because secondary plant chemicals are largely absent from grasses (Bernays \& Chapman 1978). Next to grasslands, more number of grasshoppers was collected from ground surface (33.3\%) and groundnut (21.2\%) ecosystem. Five species viz., Acrida sp., Anacridium flavascens, Epistaurus sinetyi, Trilophidia annulata and Pyrgomorpha brachycera were collected only from ground surface. The information on the type of food utilized by the ground grasshoppers could not be gathered in this study. Shelton \& Rogers (1978) and Pfadt \& Lavigne (1982) have reported that some grasshoppers feed on algae, fungi, detritus matter, humus and moss found on ground. Braker (1989) has reported that most of the grasshoppers, particularly the members of the superfamily Acridoidea lay eggs in soil. Hence the grasshoppers collected from the ground surface in the present study might be algal, detritous, humus or moss feeders or they might have come to the ground for egg laying.

The rice ecosystem supported four acridid species viz., Aiolopus thalassinus tamulus, Catantopus pinguis innotabilis, Spathosternum prasiniferum prasiniferum and Truxalis indica and one tettigoniid, Euconocephalus pallides, which constituted $15.2 \%$ of total grasshoppers collected. In the irrigated rice ecosystem in Madurai, Tamil Nadu, Kandibane et al. (2004) have collected 21 species of grasshoppers under three families such as Acrididae (71.4\%), Tettigoniidae (23.8\%) and Pyrgomorphidae (4.7\%). They reported that Oxya nititula and O. fuscovittata were the common and dominant taxa in rice ecosystem. In the present study, these two species have been recorded but not in rice field.

Among the nine localities, maximum number of grasshopper species was collected from Manimangalam during 2004-2005 (22 species) and 2005-2006 (23 species). Least number of species was recorded from Nungambakkam during 2004-2005 (12 species) and 2005-2006 (10 species) (Figure 1). Mayya et al. (2005) have stated that anthropogenic activities and pollution affected the grasshopper diversity in Dakshina Kannada District, Karnataka. Hence, the low species richness in Nungambakkam might be due to the anthropogenic activities and pollution since it is located inside the city where automobile pollution is more.

In this study, 24 species $(72.7 \%)$ were collected from only one type of habitat or host plant. This finding suggested that most of the grasshoppers are highly selective to host plants or habitats and it coincides with the statement of Mulkern (1967). According to him, most grasshoppers are selective to some degree, exhibiting definite plant preferences. Three species were collected from two types of habitats and six species were collected from more than two habitats. Among the different species, the painted grasshopper Poekilocerus pictus, a pyrgomorphid, was collected from many different host plants such as Calotropis, curry leaf, grass, groundnut and okra in 
Table 1. Grasshopper species collected from different crops, weeds and adjacent habitats in two districts of Tamil Nadu

\begin{tabular}{|c|c|c|c|c|}
\hline SNo & Species & Sub Family & Family & Habitat \\
\hline 1 & Acrida exaltata (Walk.) & Acridinae & Acrididae & Grass \\
\hline 2 & Acrida sp. & Acridinae & Acrididae & Soil \\
\hline 3 & Acrotylus humbertianus Saussure & Oedipodinae & Acrididae & Groundnut \\
\hline 4 & Aiolopus thalassinus tamulus (Fabricius) & Oedipodinae & Acrididae & Grass, rice \\
\hline 5 & Anacridium flavascens (Fabricius) & Cyrtacanthacridinae & Acrididae & Soil \\
\hline 6 & Catantops pinguis innotabilis (Walker) & Catantopinae & Acrididae & Grass, groundnut, rice, soil \\
\hline 7 & Catantops sp. & Catantopinae & Acrididae & Grass \\
\hline 8 & Cyrtacanthacris tatarica tatarica (Linn.) & Cyrtacanthacridinae & Acrididae & Tapioca \\
\hline 9 & Dnopherulasp. & Truxalinae & Acrididae & Grass \\
\hline 10 & Epistaurus sinetyi Bolivar & Catantopinae & Acrididae & Soil \\
\hline 11 & Epistaurus sp. & Catantopinae & Acrididae & Grass \\
\hline 12 & Eyprepocnemis alacris alacris (Serville) & Eyprepocnemidinae & Acrididae & Cotton \\
\hline 13 & Heteracris pulcher (Bol.) & Eyprepocnemidinae & Acrididae & Maize \\
\hline 14 & Oxya fuscovittata (Marschall) & Oxyinae & Acrididae & Grass \\
\hline 15 & Oxya hyla hyla (Serville) & Oxyinae & Acrididae & Grass, soil, brinjal \\
\hline 16 & Oxya nitidula (Walker) & Oxyinae & Acrididae & Groundnut \\
\hline 17 & Oxya sp. & Oxyinae & Acrididae & Grass \\
\hline 18 & Phlaeobida sp. & Truxalinae & Acrididae & Grass \\
\hline 19 & Spathosternum prasiniferum prasiniferum (Walker) & Truxalinae & Acrididae & Rice \\
\hline 20 & Trilophidia annulata (Thunberg.) & Oedipodinae & Acrididae & Soil \\
\hline 21 & Truxalis indica (Boliver) & Truxalinae & Acrididae & Grassland, rice, brinjal \\
\hline 22 & Atractomorpha crenulata (Fab.) & Pyrgomorphinae & Pyrgomorphidae & Brinjal, grass \\
\hline 23 & Orthacris sp. & Pyrgomorphinae & Pyrgomorphidae & Grass, groundnut, Okra, soil \\
\hline 24 & Poekilocerus pictus (Fabricius) & Pyrgomorphinae & Pyrgomorphidae & Okra, curry leaf, Grass, soil, Calotropis, groundnut \\
\hline 25 & Pyrgomorpha brachycera (Walk.) & Pyrgomorphinae & Pyrgomorphidae & Soil \\
\hline 26 & Pyrgomorphasp. & Pyrgomorphinae & Pyrgomorphidae & Grass, soil \\
\hline 27 & Conocephalus sp. & Conocephalinae & Tettigoniidae & Grass \\
\hline 28 & Elimaea sp. & Phaneropterinae & Tettigoniidae & Groundnut \\
\hline 29 & Euconocephalus pallidus (Redtb) & Copiphorinae & Tettigoniidae & Rice \\
\hline 30 & Euconocephalus sp. & Copiphorinae & Tettigoniidae & Grass \\
\hline 31 & Himertula sp. & Phaneropterinae & Tettigoniidae & Grass, soil, groundnut \\
\hline 32 & Trigonocorypha unicolor (Stoll) & Phaneropterinae & Tettigoniidae & Cotton \\
\hline 33 & Sp. 1 & - & Tetrigidae & Okra \\
\hline
\end{tabular}

- unknown

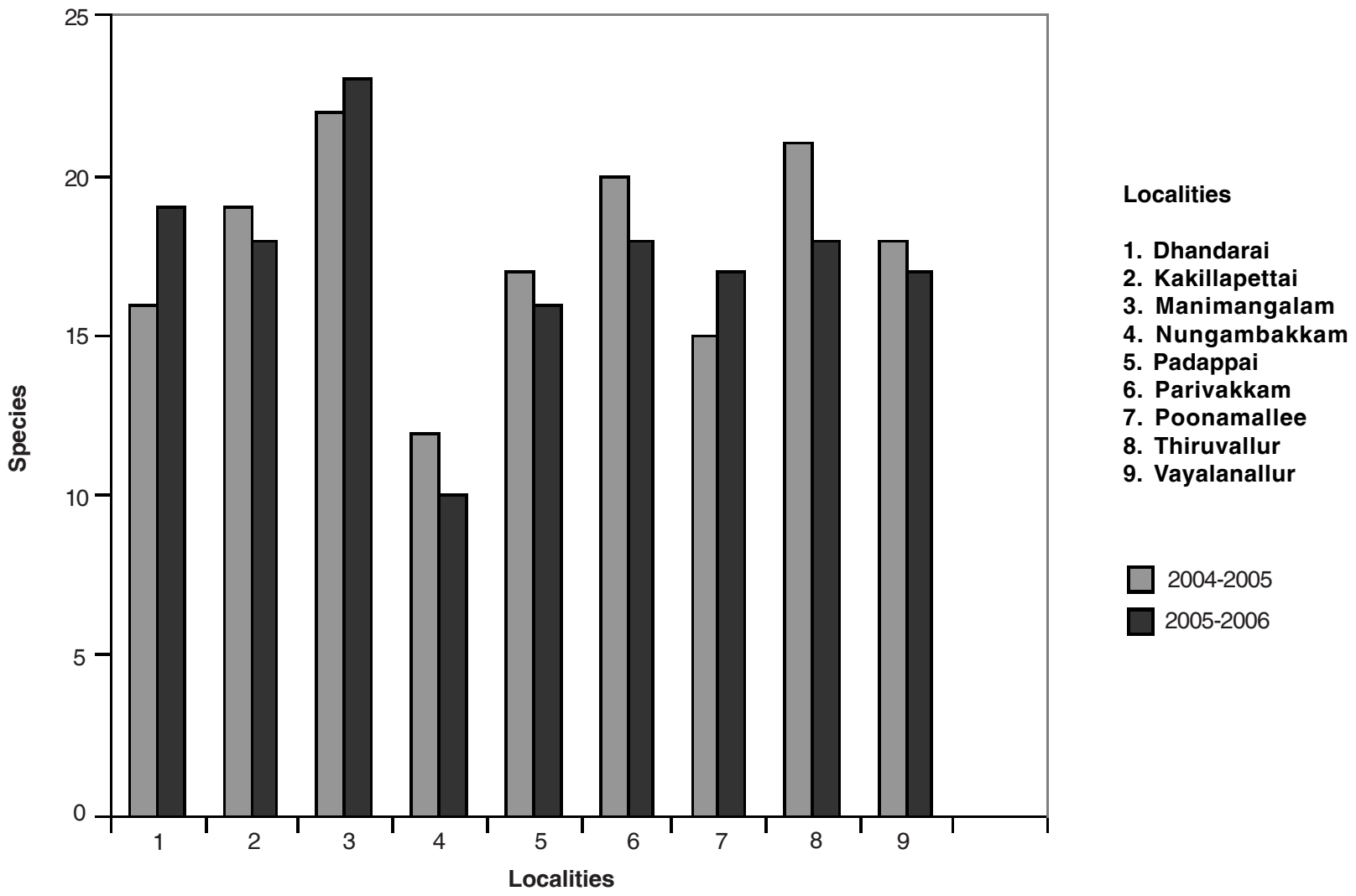

Figure 1. Total number of grasshopper species recorded from different localities in northeastern Tamil Nadu during 2004 to 2006 
Table. 2. Percentage of grasshopper species collected from different habitats

\begin{tabular}{lll}
\hline $\begin{array}{l}\text { Associated } \\
\text { habitat }\end{array}$ & $\begin{array}{l}\text { Number of species } \\
\text { recorded }\end{array}$ & $\begin{array}{l}\text { Percentage } \\
\text { of species }\end{array}$ \\
\hline Brinjal & 3 & 9.1 \\
Calotropis & 1 & 3.0 \\
Cotton & 2 & 6.1 \\
Curry leaf & 1 & 3.0 \\
Grass & 18 & 54.5 \\
Groundnut & 7 & 21.2 \\
Maize & 1 & 3.0 \\
Okra & 3 & 9.1 \\
Rice & 5 & 15.2 \\
Soil & 11 & 33.3 \\
Tapioca & 1 & 3.0 \\
\hline
\end{tabular}

Kakillapettai, Manimangalam, Nungambakkam, Padappai and Parivakkam. Once $P$. pictus was an oligophagous grasshopper feeding on milkweed plant alone and was forced to extend its host range to different taxa due to non-availability of its natural hosts, evolving into a more flexible oligophagous insect. Pruthi (1954), Batra (1955) and Bindra (1958) have recorded host shifting of $P$. pictus from Calotropis procera (in northern India) and $C$. gigantia (in southern India) to many horticultural plants. According to Bindra (1958) the selection of food plant by $P$. pictus depends on the plant species available, the grasshopper's intrinsic likes and dislikes and whether it has previously been starved. Tettigoniids, the long-horned grasshoppers are significantly important orthopterans since they sometimes encounter other insects. According to Shepard et al. (1987), the Tettigoniid Conocephalus sp. is a predator of rice bug and stem borer eggs as well as planthopper and leafhopper nymphs. They also reported that each predator can consume 3 to 4 yellow stem borer egg masses a day.

A thorough understanding of the relationship between habitat type and distribution of herbivorous insects like grasshopper is necessary to achieve crop health through ecologically based pest management. The present findings indicate that grasses inside and around the fields supported a large number of grasshopper species. Hence, the cultivation technique can be modified in such a way that the preferable host plants like grasses may be grown around the field. This will reduce crop damage. Long-term studies on grasshopper distribution among different host plants in agroecosystems are necessary to monitor the impact of modern agriculture on host plant shifting and the relative abundance of grasshoppers on various crops.

\section{References}

Andersen, A.N., L.M. Lowe \& D.C.F. Rentz (2000). The grasshopper (Orthoptera: Acridoidea, Eumastacoidea and Tettigonioidea) fauna of Kakadu National Park in the Australian seasonal tropics: biogeography, habitat associations and functional groups. Australian Journal of Zoology 48(4): 431-442

Batra, H.M. (1955). The 'AK' grasshopper Poekilocerus pictus Fab. (Acrididae) as a pest of Papaya and some other plants in Delhi. Indian Journal of Entomology 17: 132

Bernays E.A. \& R.F. Chapman (1978). Plant chemistry and acridoid feeding behaviour. In: Harborne H.B. (ed.). Biochemical Aspects of Plant and Animal Coevolution 99: 41. Academic Press

Bindra O.S. (1958). Food preference of Poekilocerus pictus Fab. - a pest of some horticultural plants at Gwalior. Indian Journal of Horticulture 15: 80-86

Capinera, J.L., C.W. Scherer \& J.B. Simkins (1997). Habitat associations of grasshoppers at the Macarthur agro-ecology research center, Lake placid, Florida. Florida Entomologist 80(2): 253-261

Chandra, K., S.K. Gupta \& M.S. Shishodia (2007). A checklist of Orthoptera of Madhya Pradesh and Chhattisgarh. Zoos' Print Journal 22(5): 26832687.

Braker, H.E. (1989). Evolution and ecology of oviposition on host plants by acridoid grasshoppers. Biological Journal of the Linnean Society 38(4): 389-406

Isely, F.B. (1944). Correlation between mandibular morphology and food specificity in grasshoppers. Annals of Entomological Society of America 37: 47-67

Joshi, P.C., J.A. Lockwood, N. Vashishth \& A. Singh (1999). Grasshopper (Orthoptera: Acridoidea) community dynamics in a moist deciduous forest in India. Journal of Orthoptera Research 8: 17-23.

Kandibane, M., S. Raguraman, N. Ganapathy \& K. Gunathilagaraj (2004). Orthopteran diversity in irrigated rice ecosystem in Madurai, Tamil Nadu. Zoos' Print Journal 19(10): 1663-1664.

Mayya, S., K.S. Sreepada \& M.J. Hegde (2005). Survey of short-horned grasshoppers (Acrididae) from Dakshina Kannada District, Karnataka. Zoos' Print Journal 20(9): 1977-1979.

Mulkern, G.B. (1967). Food selection by grasshoppers. Annual Review of Entomology 12: 59-78

Muralirangan, M.C., C. Shrinivasan \& P. Suresh (1992). Studies on short-horned grasshoppers (Acridoidea) of Tamil Nadu. Part II. Hemiacridinae, Oxyinae, Coptacridinae, Tropidopolinae, Caloptinae, Eyprepocnemidinae, Catantopinae and Cyrtacanthacridinae. Hexapoda 4: 149-166.

Pfadt, R.E \& R.J. Lavigne (1982). Food habits of grasshoppers inhabiting the Pawnee site. Sci. Monogr. 42, Univ. Wyoming Agric. Exp. Sta. Laramie.

Pruthi, H.S. (1954). The 'AK' grasshopper Poekilocerus pictus (Fabr.) (Acrididae) attacking citrus in Delhi. Indian Journal of Entomology 16: 196

Risser, P.G., E.C. Birney, H.D. Blocker, S.W. May, W.J. Parton \& J.A. Wiens (1981). The true prairie ecosystem. Hutchinson Ross Pub. Co., Stroudsburg, Penn, 557pp.

Sanjayan, K.P., M.C. Muralirangan, P. Suresh, D.S. Chand \& S. Albert (1995). Insect diversity in a natural scrub-jungle vegetation of a forest ecosystem in Tamil Nadu, India. The Entomologist 114: 179194

Scott, J.A., N.R. French \& J.W. Leetham (1979). Pattern of consumption in grasslands, pp. 89-105. In: French, N.R. (ed.) Perspectives in Grassland Ecology. Springer-Verlag, New York.

Shelton, J.K. \& L.E. Rogers (1978). Grasshopper food habits within a shrub-steppe community, Oecologia 32: 93-100

Shepard, B.M., A.T. Barrion \& J.A. Litsinger (1987). Friends of the Rice Farmer-helpful Insects, Spiders and Pathogens. International Rice Research Institute, Philippines.

Shrinivasan, C. \& M.C. Muralirangan (1992). Studies on short-horned grasshoppers (Acridoidea) of Tamil Nadu Part I: Acridinae, Truxalinae, Comphocerinae and Locustinae. Hexapoda 4: 13-26.

Thakur, S.K., M.S. Shishadia, H.S. Mehta \& V.K. Mattu (2004). Orthopteran diversity of Roper Wetland Punjab, India. Zoos' Print Journal 19(11): 1697. 